\title{
Diversity of hoverflies (Diptera: Syrphidae) in Nagarjun, Shivapuri Nagarjun National Park, Nepal
}

\author{
NABIN BUDHATHOKI ${ }^{1, \boldsymbol{v}}$, SUSHMA DHAKAL ${ }^{1}$, URMILA DYOLA $^{2}$ \\ ${ }^{1}$ Department of Zoology, Amrit Campus, Tribhuvan University. Amrit Marg, Thamel, Kathmandu 44600, Nepal. Tel.: +977-9845423366, \\ vemail: nabinbthoki191@gmail.com \\ ${ }^{2}$ Central Department of Zoology, Institute of Science and Technology, Tribhuvan University. Kirtipur, Kathmandu 44618, Nepal
}

Manuscript received: 3 October 2021. Revision accepted: 17 November 2021.

\begin{abstract}
Budhathoki N, Dhakal S, Dyola U. 2021. Diversity of hoverflies (Diptera: Syrphidae) in Nagarjun, Shivapuri Nagarjun National Park, Nepal. Biodiversitas 22: 5382-5388. Hoverflies are recognized as potential pollinators of a wide range of wild plants. This study explored the abundance and diversity of hoverflies over three different seasons from October 2018 to April 2019 in two different study sites, i.e. forest and grassland at Nagarjun of Shivapuri Nagarjun National Park, Nepal. Each site of the study area was further divided into five sampling transect stations. Hoverflies were collected from each station by using two methods as pan trap sampling and transect sweeping sampling. Overall, a total of 373 specimens representing 13 species under nine genera of two subfamilies (Syrphinae and Eristalinae) were recorded. The abundance and diversity of hoverflies varied seasonally, the maximum number of individuals and diversity were recorded from the spring season, whereas the minimum number of individuals and diversity were found in the winter season. In addition, forest habitat consists of the highest abundance and diversity of hoverflies, whereas grassland consists of the lowest abundance and diversity. The analysis done by using generalized linear modeling (GLM) revealed climatic parameters such as temperature and humidity had a varying effect on the abundance of hoverflies. However, both these parameters had not any significant influence on the number of hoverfly species.
\end{abstract}

keywords: Abundance, climatic parameters, habitats, species richness, syrphids

\section{INTRODUCTION}

Syrphidae (Hoverflies or flower flies) is one of the most diverse families of the Diptera with approximately 6000 known species under 200 genera worldwide and can be found on everywhere except Antarctica and remote oceanic islands (Thompson et al. 2010; Rotheray and Gilbert 2011). More than 185 species are recorded in Nepal (Clauben and Weipert 2004). Most species occupy a significant part in different ecosystems, as important pollinators (PiekarskaBoniecka et al. 2015), aphid predators and recyclers of decomposing matter (Rotheray and Gilbert 2011). Hoverflies are considered as potential pollinators of a wide range of wild plants (Inouye et al. 2015; Doyle et al. 2020) that can provide the same amount of pollination services as bees in some conditions (Ellis et al. 2017). The adult hoverflies mainly depend upon the nectar of flowering plants for their food and energy, whereas females use pollen for ovarian maturation (Doyle et al. 2020). The major identifying character is the presence of spurious vein or false vein (few exceptions in genera Graptomyza and Paragodon along with species Syritta flaviventris), which lies between the third $(\mathrm{R} 4+5)$ and fourth $(\mathrm{M} 1+2)$ longitudinal veins of the wings extending longitudinally and slightly diagonally (Sengupta et al. 2018). Some hoverfly species are specific in their habitat preferences and thus, exhibit a narrow distributional range, whereas some species have a wide distributional range across several habitats (Sengupta et al. 2016). Generally, the requirements and behavior of the species within the genus are similar (Ghahari et al. 2008). Therefore, certain genera normally inhabit particular habitats. Important structural components like certain flowers or egg-laying sites can lead to differences in the horizontal distribution of the adults at a site within a habitat (Stubbs and Falk 2002).

Biodiversity is under a huge amount of pressure on a global level due to the ever-growing impact of human activities (Pimm et al. 2014; Janković et al. 2020). Characteristics such as cosmopolitan distribution, the presence of great taxonomic literature for the identification of European species and the variation in the degree of mobility among species for different geographical regions show that hoverflies could serve as good indicators of biodiversity (Sommaggio and Burgio 2014; Popov et al. 2017; Noel et al. 2021). Hoverflies are generally mobile species, so they could be good bioindicators on landscape scales, whereas few philopatric species could be utilized as biodiversity indicators on microhabitat levels (Talasova et al. 2018). Besides the complex relationships between pollinators and plants, recognizing the role of hoverflies in the ecosystem requires understanding their taxonomy, abundance, diversity, and responses to climatic factors (Gaytán et al. 2020; Ela et al. 2021). The information about hoverfly communities concerning biotic and abiotic factors has been generally documented with the concept of establishing many conservation strategies (Shebl et al. 2008) that can help to avoid the loss of many wild plant species, prevent the decline in crop production and 
maintain the ecological balance (Rotheray and Gilbert 2011).

Despite the broad distribution pattern and enormous economic importance, there has been limited research work on hoverflies in Nepal and studies were restricted to the checklist or basic ecology of a few species. This research was focused on exploring the diversity of hoverflies in Nagarjun of Shivapuri Nagarjun National Park (SNNP), which is known as a biodiversity-rich area in Central Nepal. Furthermore, the study was conducted to: (i) assess the abundance and species richness of hoverflies throughout the study period; (ii) determine the seasonal variation; (iii) compare the hoverfly communities in two different habitats (forest and grassland); and (iv) examine the relation of hoverfly fauna with different climatic parameters (temperature and humidity). The main goal of our study is to provide some valuable direction for future investigations on hoverfly diversity in Nepal.

\section{MATERIALS AND METHODS}

Shivapuri Nagarjun National Park is the only protected area that is enclosed to the mid-hills, which is important for biodiversity conservation and is a source of water supply for Kathmandu valley (DNPWC 2016). It was established in $2002 \mathrm{AD}$. The elevation range is $1350 \mathrm{~m}$ asl to $2732 \mathrm{~m}$ asl. The park lies in the middle mountain region of Nepal, geographically extending from $27^{\circ} 45^{\prime} \mathrm{N}$ to $27^{\circ} 52^{\prime} \mathrm{N}$ latitude and $85^{\circ} 16^{\prime} \mathrm{E}$ to $85^{\circ} 45^{\prime} \mathrm{E}$ longitude. This National Park is divided into two distinct areas by the roads running north from Kathmandu and many buffer zones. The larger part is originally named Shivapuri National Park, that is consists of major areas such as Shivapuri peak, Sundarijal, Kakani and Manichur. The smaller part, i.e., Nagarjun area was later added to National Park in 2009 AD, covering around $15 \mathrm{~km}$ square with an altitude ranging from $1597 \mathrm{~m}$ to $2128 \mathrm{~m}$ asl. Altogether, Shivapuri Nagargun National Park occupies an area of 159 square kilometers. The geographical range of Nagarjun is located within $27^{\circ} 43^{\prime} \mathrm{N}$ to $27^{\circ} 46^{\prime} \mathrm{N}$ latitude and $85^{\circ} 13^{\prime} \mathrm{E}$ to $85^{\circ} 18^{\prime} \mathrm{E}$ longitude.

The study sites were located in the Nagarjun area. The first study site, i.e., forest habitat, lies at $1597 \mathrm{~m}$ asl. $\left(27.74408^{\circ} \mathrm{N}, 85.28741^{\circ} \mathrm{E}\right)$. The forest comprises major tree species such as Schima wallichii, Castanopsis indica, Alnus nepalensis, Pinus roxburghii, Myrica esculenta, Pyrus pashia, Quescus semicarpifolia, Rhododendron arboreum, Juglan regia, etc. On the other hand, the second study site, i.e., grassland, lies at $1700 \mathrm{~m}$ asl. $\left(27.74424^{\circ} \mathrm{N}\right.$, $\left.85.29027^{\circ} \mathrm{E}\right)$. The grassland is comprised of some medicinal herbs such as Artemisia vulgaris, Mimosa pudica, etc. and many other plants such as Eulaliopsis binata, Cynodon dactylon, Desmostachya bipinnata, Imperata cylindrica, Thysanolaena maxima, Ageratum conyzoides, Ageratina adenophora, Bidens pilosa, etc.

\section{Study design}

Two sampling sites were selected based on habitat types, i.e., forest and grassland. The survey was conducted from September 2018 to May 2019 during three different seasons, i.e., Autumn (September-November), winter (December-February) and spring (March-May). Samples were collected in every season by using two methods as pan trap sampling and transect sweeping sampling. Both sites of the study area were further divided into five sampling transect stations. Each of those transect stations occupied a 100 sq.m area and lies in the distance of $30 \mathrm{~m}$ apart from each other.

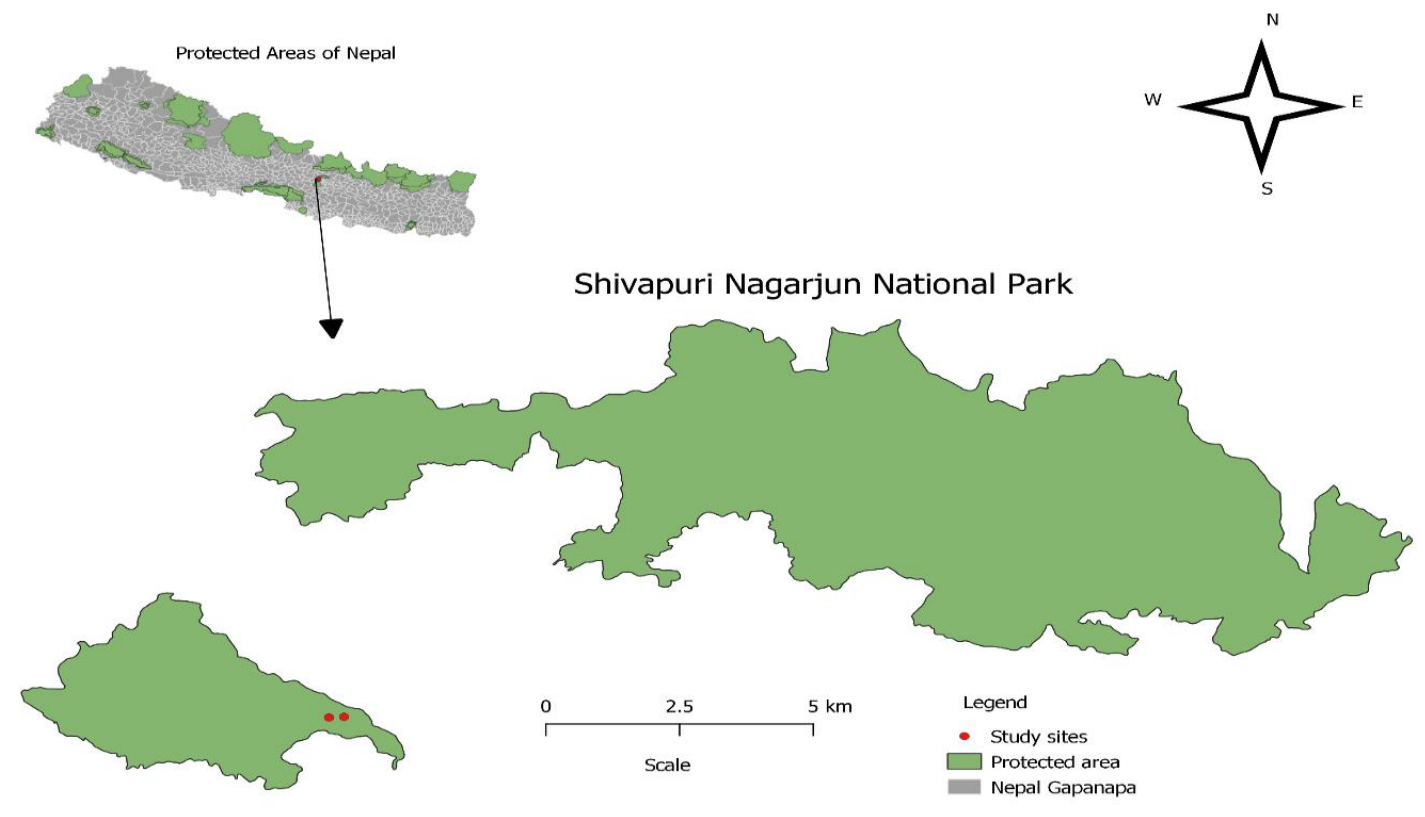

Figure 1. Map of Shivapuri Nagarjun National Park, Nepal showing the study sites 


\section{Pan trap sampling}

This method was employed once per season, i.e., Autumn (October), winter (January) and spring (April) in every sampling transect station to get the sampling coverage of both habitats. Every sampling transect station consisted of a set of three pan traps at a single location, each of different colors, i.e., white, yellow, and blue as applied by Gervais et al. (2018), each attached to a post using a metal clamp adjusting bowl in the rim. Each pan was filled with $400 \mathrm{ml}$ water and 10 drops of detergents. The pan traps were visited for sampling after 24 hours.

\section{Transect sweeping sampling}

This method was conducted in the areas around the same pan-trap transects to obtain the maximum coverage of hoverfly sampling. Sweeping was carried out on different months to the pan trap sampling. It was done for two days per season when it was sunny between 08: 00 and 17: 00 hours. Hoverflies were captured by field observers by walking in straight lines using sweeping nets (Hussain et al. 2018) on every sampling transect station of each site. We perform 30 sweeps on every transect station resulting $5 \times$ $30=150$ sweeps per study site in a day. Then the collected specimens were kept in a vial adequately labeled and then preserved inside an icebox.

\section{Identification of hoverflies}

The collected specimens were identified with the help of taxonomic literature (Ghorpade 2014; Thapa 2015; Hassan et al. 2017; Sengupta et al. 2017; Speight and Sarthou 2017).

\section{Data analysis}

Shannon-Weiner index $\left(\mathrm{H}^{\prime}\right)$ and Pielou's evenness index (J) were used to calculate the species diversity of the hoverflies of the study area over three seasons. The Bray Curtis analysis for hierarchical clustering using a single linking method was used to find out the similarities between hoverfly fauna during three different seasons. Principal component analysis (PCA) was applied to analyze the distribution patterns of hoverflies among the habitats. Furthermore, we evaluated the averages of climatic variables, i.e., temperature and humidity, from recorded data that were measured by ourselves during the sampling period on the study field using a digital thermohygrometer (HTC-2). The relationship of temperature and humidity with the species richness and abundance of hoverflies was established by generalized linear modeling (GLM). Analyses were done by using the vegan package (Oksanen et al. 2017) in R software version 3.6.1 (R Core Team 2018).

\section{RESULTS AND DISCUSSION}

\section{Abundance and species richness of hoverflies}

The study results show that a total of 373 specimens belonging to 13 species under nine genera of two subfamilies were recorded from two different habitats in Nagarjun of Shivapuri Nagarjun National Park during the study period. The sub-families Syrphinae and Eristalinae have consisted of 10 and three species respectively. The population of sub-family Syrphinae (311 individuals) was greater in abundance than that of Eristalinae (62 individuals) throughout the study period. Hoverflies representing sub-family Syrphinae were largely distributed compared to sub-family Eristalinae as also observed by previous studies (Naderloo and Rad 2014; Ansari and Memon 2017) in their findings. Species belonging to subfamily Syrphinae use a wide range of plants as their shelter, food resources, as well as breeding sites, whereas most members of Eristalinae prefer to breed in marshes, damp places, and rotting materials (Sommaggio 1999). Overall, the most predominant species was Episyrphus balteatus $(17.69 \%)$, which was followed by Sphaerophoria bengalensis $(12.86 \%)$ and Melanostoma scalare $(12.33 \%)$, whereas Scaeva pyrastri $(1.60 \%)$ was the least abundant species (Table 1).

Table 1. Classification details and abundance percentages of the collected hoverfly species in Nagarjun, Nepal

\begin{tabular}{lllc}
\hline \multicolumn{1}{c}{ Scientific names } & Sub family & Tribe & Abundance (\%) \\
\hline Eristalis cerealis & Eristalinae & Eristalini & 6.43 \\
Eristalis tenax & Eristalinae & Eristalini & 8.31 \\
Eristalinus aeneus & Eristalinae & Eristalini & 1.87 \\
Melanostoma univittatum & Syrphinae & Bacchini & 10.72 \\
Melanostoma scalare & Syrphinae & Bacchini & 12.33 \\
Dasysyrphus orsua & Syrphinae & Syrphini & 4.55 \\
Episyrphus balteatus & Syrphinae & Syrphini & 17.69 \\
Eupeodes bucculatus & Syrphinae & Syrphini & 5.36 \\
Eupeodes corollae & Syrphinae & Syrphini & 4.02 \\
Parasyrphus punctulatus & Syrphinae & Syrphini & 2.68 \\
Scaeva pyrastri & Syrphinae & Syrphini & 1.60 \\
Sphaerophoria bengalensis & Syrphinae & Syrphini & 12.86 \\
Sphaerophoria indiana & Syrphinae & Syrphini & 11.52 \\
\hline
\end{tabular}




\section{Seasonal variation of hoverflies}

The abundance of hoverfly species varied with different seasons (Table 2). Although they are known as common pollinator species throughout the year, the hoverfly abundance was higher during spring than in other seasons. Our findings were in accordance with Ball and Morris (2015). The maximum number of species and individuals was recorded in the spring season, followed by autumn. On the other hand, the minimum number of hoverfly species and individuals was collected during the winter season (Figure 2). The Shannon-Weiner index showed that the diversity of hoverflies topped during the spring season $\left(\mathrm{H}^{\prime}\right.$ : 2.38) followed by the autumn season $\left(\mathrm{H}^{\prime}: 2.31\right)$, whereas diversity was lower during the winter season $\left(\mathrm{H}^{\prime}: 1.50\right)$. The result is closely related to a study done by Naderloo and Rad (2014), which also recorded the maximum number of species as well as the highest Shannon diversity index during the spring season. This is associated with the period when flowering plant species and aphids are available in high amounts as a source of food for adults and immatures respectively (Francis et al. 2002). Besides this, Pielou's evenness was computed, which was more or less similar in all three seasons. In contrast to the diversity index, the evenness obtained was slightly higher during winter $(\mathrm{J}$ : $0.936)$ and slightly lower during the spring season ( $\mathrm{J}$ : 0.930 ), with the autumn season (J: 0.933 ) lying in between.

The similarities of hoverfly communities during three different seasons are displayed by cluster dendrogram (Figure 3). The Bray-Curtis analysis demonstrated that spring and autumn were closely related and very similar in species composition of hoverflies. In contrast to this, the winter season was less diverse and poor in abundance and species richness because of the lack of food, low temperatures, and overwintering (Kapkoti et al. 2016).

\section{Hoverfly community in two habitats}

The higher number of species and abundance of hoverflies were inhabited forest habitats than grassland throughout the study period. In total, 13 species and 210 individuals of hoverflies were recorded from forest habitats, while 11 species and 163 individuals were recorded from grassland (Figure 4). Gaytán et al. (2020) also observed the greater abundance and species richness of hoverflies in a forest than in grassland habitats. The outcome of our study can be compared with the results of a research carried out by Ricarte et al. (2011), who suggested that the highest number of species in the forest were observed possibly because of the availability of large varieties of resources, as well as the formation of different microhabitats such as over matured trees, small grasses, bodies of water (temporary or permanent), small invasive areas of scrub, forest edges, etc. The insufficient flower resources and deterioration of the nesting sites are some of the main reasons for the depletion of pollinator insects communities in open habitats such as grasslands (Goulson et al. 2015; Sanchez-Bayo and Wyckhuys 2019).

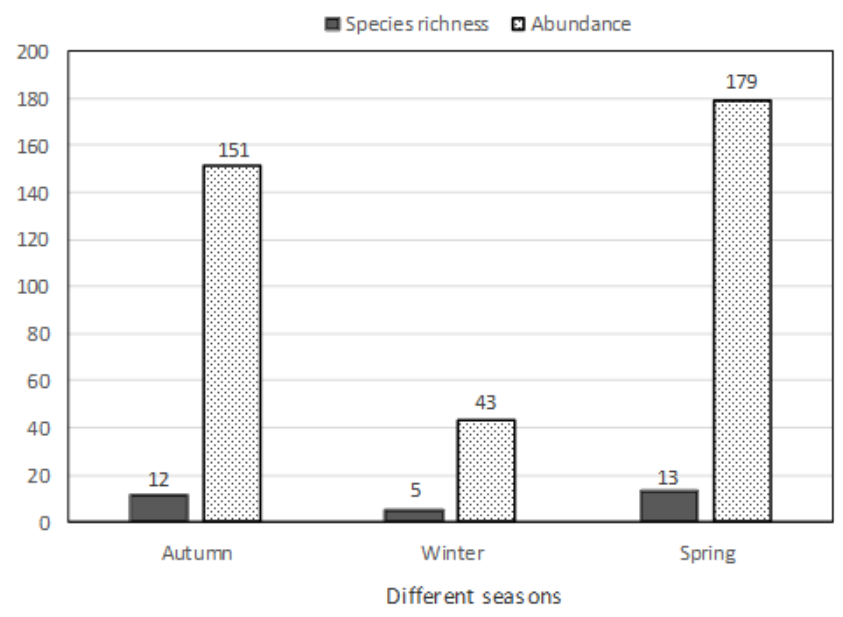

Figure 2. Species richness and abundance of hoverflies over three seasons

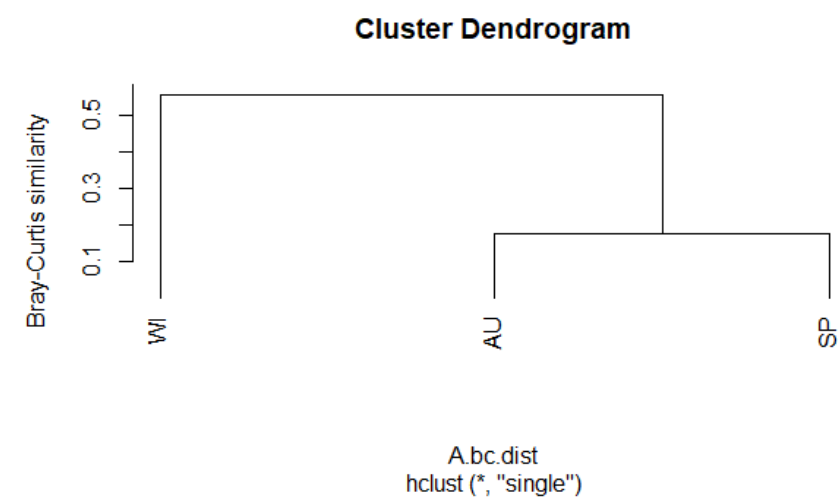

Figure 3. Bray Curtis Analysis (single linkage) for hoverflies assemblages of different seasons in Nagarjun, Nepal. Season symbols: AU-Autumn, WI-Winter, SP-Spring.

Table 2. Showing main attributes of hoverfly assemblages in Nagarjun, Nepal

\begin{tabular}{lccccc}
\hline \multicolumn{1}{c}{ Attributes } & & Seasons & \multicolumn{2}{c}{ Habitat } \\
\cline { 2 - 6 } & Autumn & Winter & Spring & Forest & Grassland \\
\hline Number of species & 12 & 5 & 13 & 13 & 11 \\
Number of specimens & 151 & 43 & 179 & 210 & 163 \\
Shannon-Wiener index (H') & 2.31 & 1.50 & 2.38 & 2.36 & 2.18 \\
Pielou's evenness index (J) & 0.933 & 0.936 & 0.930 & 0.920 & 0.912 \\
\hline
\end{tabular}




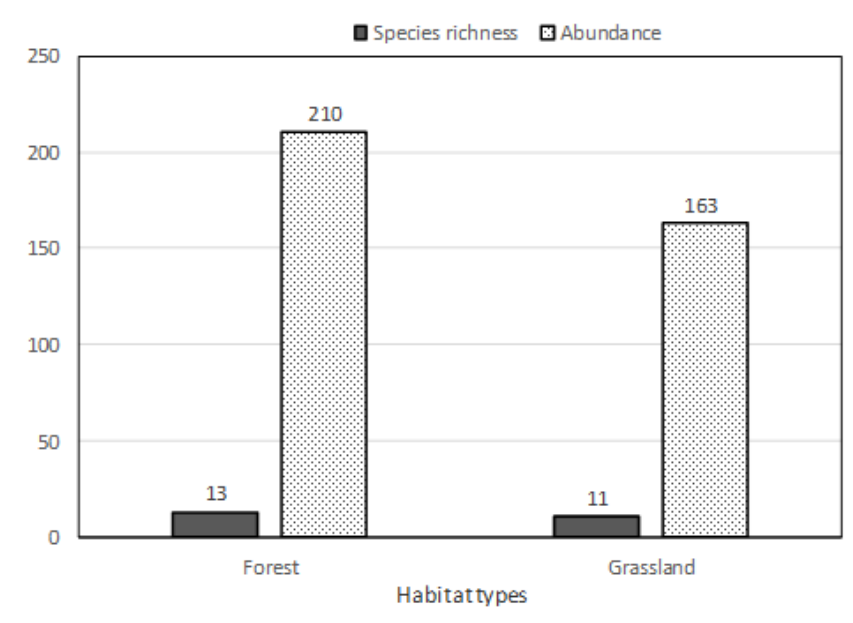

Figure 4. Species richness and abundance of hoverflies in two habitats in Nagarjun, Nepal

The Shannon-Weiner index indicated that the forest habitat $\left(\mathrm{H}^{\prime}\right.$ : 2.36) was more diverse than grassland $\left(\mathrm{H}^{\prime}\right.$ : 2.18). The evenness of hoverflies was slightly better throughout the forest ( $\mathrm{J}: 0.920)$ than in the grassland habitat (J: 0.912). The result is similar to the finding of an investigation done by Markov et al. (2018) through two different habitats: forest and grassland. The greater diversity of vegetation in forest habitat than in grassland leads to a greater diversity of hoverflies, as concluded by Naderloo and Rad (2014) in their research conducted through different habitats.

\section{Principal Component Analysis (PCA)}

The PCA was conducted to identify the influence of two different habitat types on the abundance of hoverfly communities (Table 3). The PCA generated two principal components (PC axes), the first principal component (PC1) explained $75.1 \%$ of the total variation, whereas the second principal component (PC2) explained $24.9 \%$ of the total variation (Figure 5). The PCA showed that Episyrphus balteatus was the most dominant as well as evenly abundant species in both habitats. Episyrphus balteatus exhibited a broad range of geographical distribution (Ghahari et al. 2008) and was attracted to large varieties of plants (Sajjad et al. 2010). Apart from that, most of the hoverfly species such as Melanostoma scalare, Melanostoma univittatum, Eristalis tenax, Eristalis cerealis, Eristalinus aeneus, Dasysyrphus orsua and Parasyrphus punctulatus were frequently associated with forest habitat. Our study sites on forest habitat consisted the large varieties of woody and flowering plants, as well as trees. The conclusion of Ricarte et al. (2011), can be related to the abundance and evenness of Syrphidae communities, which indicated that forest habitat was more suitable for hoverflies than grassland because it prevents them from unfavorable conditions such as wind, rain, extreme temperatures, sun irradiations, water scarcity, predators, etc. Therefore, most hoverfly species used the forest for shelter, pollen resources and breeding sites (Hurkmans 1993). On the other hand, individuals belonging genus Sphaerophoria and Eupeodes, as well as the species Scaeva pyrastri were generally found in grassland. These hoverflies were likely to be preferred open grassy clearings and herbaceous plants offered by grassland as their egglaying sites and food resources. Furthermore, the presence of grassy clearings supported the prey populations such as aphids which could be contributed to the predatory hoverfly community (Ricarte 2008).

\section{Relation of climatic parameters with hoverfly communities}

The analysis done using generalized linear modeling (GLM) with Poisson regression indicated an association between temperature and humidity with hoverfly assemblages throughout the study period. The GLM revealed that both temperature $(\mathrm{z}: 8.410, \mathrm{p}<2 \mathrm{e}-16)$ and humidity (z: 3.768, p: 0.000165) significantly influenced the abundance of hoverflies (Table 4). However, both temperature (z: 1.833, p: 0.0597) and humidity (z: 0.834, p: 0.4042 ) were found to be not significant and didn't have any remarkable relation with species richness (Table 5).

Table 3. Summary of Principal Component Analysis

\begin{tabular}{lcc}
\hline \multicolumn{1}{c}{ Attributes } & PC1 & PC2 \\
\hline S.D. & 1.2256 & 0.7056 \\
Proportion of variance & 0.7511 & 0.2489 \\
Cumulative proportion & 0.7511 & 1 \\
\hline
\end{tabular}

Table 4. Relation of climatic parameters with abundance of hoverflies (Generalized linear modelling with Poisson regression using log link function)

\begin{tabular}{lcccc}
\hline \multicolumn{1}{c}{ Factors } & Estimate & $\begin{array}{c}\text { Std. } \\
\text { Error }\end{array}$ & z value & p-value \\
\hline Temperature & 0.223876 & 0.026621 & 8.410 & $<2 \mathrm{e}-16$ \\
Humidity & 0.029320 & 0.007781 & 3.768 & 0.000165 \\
\hline
\end{tabular}

Table 5. Relation of climatic parameters with species richness of hoverflies (Generalized linear modelling with Poisson regression using $\log$ link function)

\begin{tabular}{lcccc}
\hline \multicolumn{1}{c}{ Factors } & Estimate & $\begin{array}{c}\text { Std. } \\
\text { Error }\end{array}$ & z value & p-value \\
\hline Temperature & 0.15191 & 0.08069 & 1.883 & 0.0597 \\
Humidity & 0.02200 & 0.02638 & 0.834 & 0.4042 \\
\hline
\end{tabular}




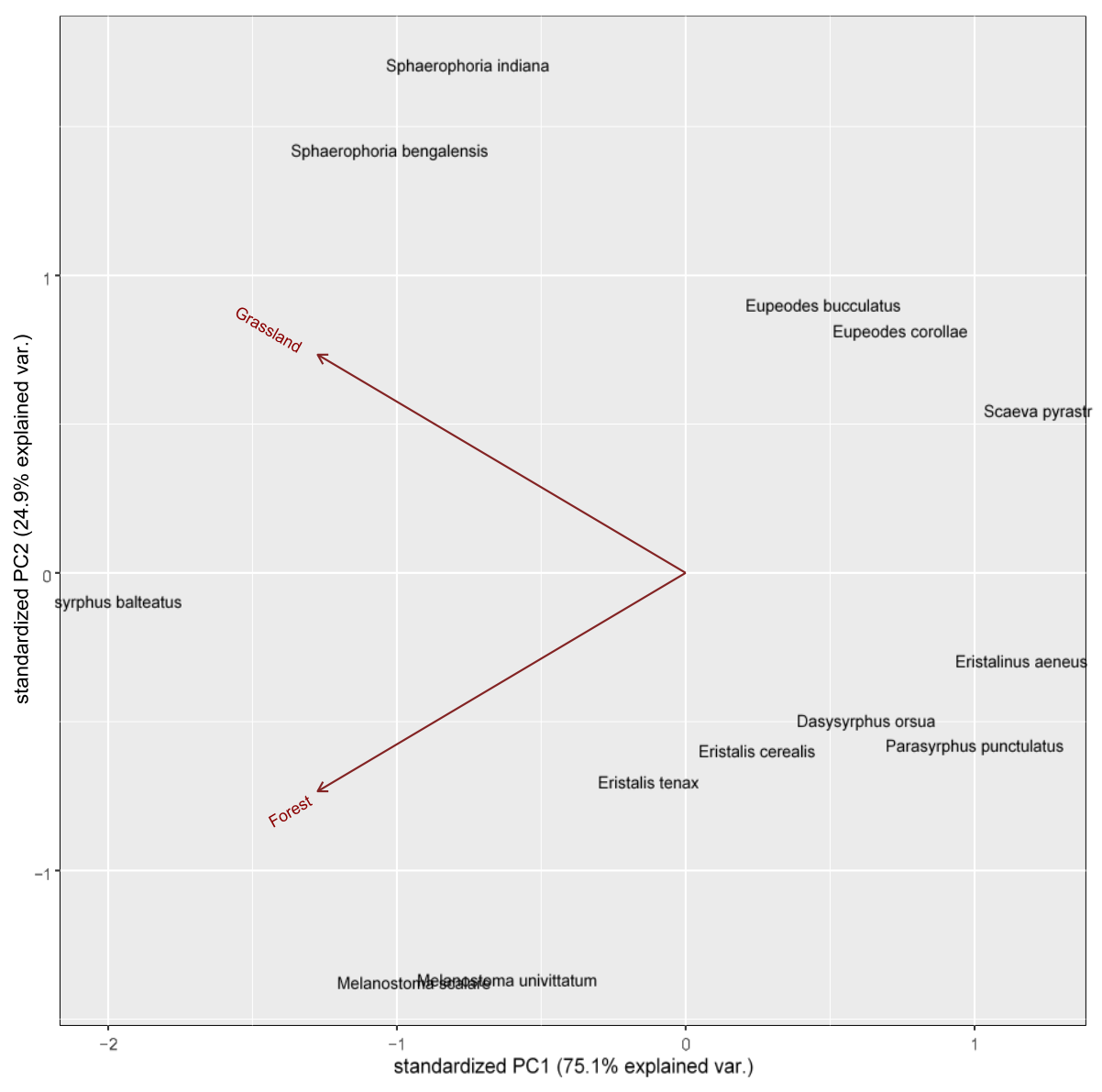

Figure 5. Biplot of the principal component analysis (PCA) for hoverfly community of two habitats in Nagarjun, Nepal

This shows that the winter season was poor in the abundance of many hoverflies species since it was the coldest time of the year. In contrast to this, the number of individuals was observed high during the spring season since it was the warm season of all. Meanwhile, relative humidity had a slightly negative influence on abundance, whereas there was no relation with species richness throughout the study period. According to Polatto et al. (2014), scarcity of floral resources caused by unfavorable abiotic factors such as temperature and humidity are responsible for pollinators' adverse impact on plant visitations. The results are associated with the findings of Carvalho et al. (1991), which also suggested that the relation of temperature with abundance was positive with a higher number of hoverflies observed during the hot season compared to the cold season, although the relation between pollinators, including hoverflies and climatic factors, may vary with geographical distribution. In hot and humid climates with no dry season, climatic factors such as temperatures and humidity could negatively affect hoverfly assemblages (Sajjad et al. 2010; Ansari and Memon 2017).

In conclusion, this study provides a faunistic analysis of hoverflies in two different habitats over three different seasons. The forest habitat having high species richness and abundance had higher diversity than that of grassland habitat. In addition, the spring season was most favorable for hoverflies which resulted in a maximum number of individuals and species of hoverflies as well as maximum diversity. On the other hand, the winter season had the least number of individuals and lowest species richness, as well as the lowest diversity. Two seasons such as spring and autumn, were closely related in species composition as compared to the winter season. Two major climatic parameters such as temperature and humidity, influenced the number of individuals of hoverflies during the study period. As for species richness, both parameters didn't play a significant role in shaping the diverse varieties of species throughout the study period.

In recommendation, extensive research covering all seasons in different habitats is necessary for a better understanding of hoverfly diversity in this region. It will help to promote the importance of hoverfly pollination in different plants and play a crucial role in developing and implementing conservation strategies in Nepal.

\section{ACKNOWLEDGEMENTS}

We would like to express our sincere gratitude to the Department of National Parks and Wildlife Conservation (DNPWC), Kathmandu, for the permission to conduct this survey in Nagarjun. Furthermore, we are very grateful to all the staff members of the Department of Zoology, Amrit 
Campus, for their cooperation and support in carrying out this work. Similarly, we would like to give credit to the Entomology Laboratory, Central Department of Zoology, Tribhuvan University for the allowance to perform our laboratory works. Also thankful to supervisor Urmila Dyola, Assistant professor, Central Department of Zoology, Tribhuvan University, for her continuous support, guidance, suggestion, and encouragement during the study. Thanks also go to our friends Arjun Khadka, Prakash Timalsina and Manisa Singh for their involvement in the field data collection. There are not any conflicts of interest concerning the research, authorship and publication of this article.

\section{REFERENCES}

Ansari A, Memon N. 2017. Seasonal variation and diversity of hoverflies fauna (Diptera: Syrphidae) in Central Sindh, Pakistan. Sarh J Agric 33 (4): 653-660. DOI: 10.17582/journal.sja/2017/33.4.653.660.

Ball S, Morris R. 2015. Britain's Hoverflies: A Field Guide. Princeton University Press, New Jersey, United States.

Carvalho AMC, Mendes J, Marchiori CH, Lomonaco C. 1991. Variacao espacial e sazonal de dipterous muscoideos em duas areas de cerrado no municipio de Uberlandia-MG. I Calliphoridae e Muscidae. R Cent Ci Biomed Univ Fed Uberlandia 7: 27-34.

Clauben CJ, Weipert J. 2004. Notes on the subgenus Paragus (Pandasyopthalmus) (Diptera, Syrphidae) from Nepal, with the description of a new species. Volucella 7: 75-88.

DNPWC. 2016. Shivapuri Nagarjun National Park (Brochure) DNPWC/Shivapuri Nagarjun National Park, Panimuhan, Kathmandu, Nepal. www.snnp.gov.np.

Doyle T, Hawkes WLS, Massy R, Powney GD, Menz MHM, Wotton KR. 2020. Pollination by hoverflies in the Anthropocene. Proc R Soc B 287: 20200508 DOI: 10.1098/rspb.2020.0508.

Ela MA, Wangbara BB, Jordaens K. 2021. Diversity of flower-visiting hoverflies (Diptera: Syrphidae) on ground cover vegetation from the market-gardening area of Meskine (Far-North Region, Cameroon). Afr J Ecol 00: 1-9. DOI: 10.1111/aje.12922.

Ellis CR, Feltham H, Park K, Hanley N, Goulson D. 2017. Seasonal complementary in pollinators of soft-fruit crops. Basic Appl Ecol 19: 45-55. DOI: 10.1016/j.baae.2016.11.007.

Francis F, Haubruge E, Colignon P, Hastir P, Gaspar C. 2002. Entomological diversity in agro-ecosystems: Not necessarily an ecological desert. Biologie 72: 153-154.

Gaytán Á, Ricarte A, González-Bornay G. 2020. Hoverfy diversity (Diptera: Syrphidae) of Pyrenean oak woodlands in Central-Western Spain: a preliminary study with conservation outcomes. J Insect Conserv 24: 163-173. DOI: 10.1007/s10841-019-00208-z.

Gervais A, Chagnon M, Fournier V. 2018. Diversity and pollen loads of flower flies (Diptera: Syrphidae) in Cranberry Crops. Ann Entomol Soc Am 111 (6): 326-334. DOI: 10.1093/aesa/say027.

Ghahari H, Hayat R, Tabari M, Ostovan H. 2008. Hoverflies (Diptera: Syrphidae) from rice fields and around grasslands of northern Iran. Mun Ent Zool 3 (1): 275-284.

Ghorpade KD. 2014. An updated check-list of the hover-flies (DipteraSyrphidae) recorded in the Indian subcontinent. Colemania 44: 1-30.

Goulson D, Nicholls E, Botias C, Rotheray EL. 2015. Bee declines driven by combined stress from parasites, pesticides, and lack of flowers. Science 347 (6229): 1255957-1255957. DOI: 10.1126/science. 1255957.

Hassan MA, Ghorpade K, Mahmood K, Shehzad A, Nazir N, Fatima N 2017. Preliminary studies on the Syrphidae (Diptera) of Poonch district, Azad Kashmir, Pakistan. Orient Insects 52 (3): 1-19. DOI: 10.1080/00305316.2017.1394924.

Hurkmans W. 1993. A monograph of Merodon (Diptera: Syrphidae). Part 1. Tijdschr Entomol 136: 147-234.

Hussain RI, Walcher R, Brandl D, Arnberger A, Zaller JG, Frank T. 2018 Efficiency of two methods of sampling used to assess the abundance and species diversity of adult Syrphidae (Diptera) in mountainous in the Austrian and Swiss Alps. Eur J Entomol 115: 150-156. DOI: 10.14411/eje.2018.014.

Inouye DW, Larson BH, Ssymank A, Kevan P. 2015. Flies and flowers III: Ecology of foraging and pollination. J Pollinat Ecol 16: 115-133. DOI: $10.26786 / 1920-7603(2015) 15$.

Janković M, Miličić M, Ačanski J, Vujić A. 2020. Protected areas and prime hoverfly areas: Safe haven for hoverflies or not? Entomol Sci 23 (2): 173-182. DOI: 10.1111/ens.12411.

Kapkoti B, Joshi RK, Rawal RS. 2016. Variations in the abundance and diversity of insects in apple orchards of Kumaun, Western Himalaya, India. Curr Sci 110 (3): 438-443.

Markov ZZ, Popov SD, Mudri-Stojnić SJ, Radenković SR, Vujić AA. 2018. Hoverfly diversity assesment in grassland and forest habitats in Autonomous Province of Vojvodina based on a recent monitoring study. Zb Matice Srp Prir Nauke 135: 93-102. DOI: 10.2298/ZMSPN1835093M.

Naderloo M, Rad SP. 2014. Diversity of Hoverfly (Diptera: Syrphidae) communities in different habitat types in Zanjan Province, Iran. Intl Sch Res Not 2014: 162343. DOI: 10.1155/2014/162343.

Noel G, Bonnet J, Everaerts S, Danel A, Calderan A, de Liedekerke A, d'Annevoie CM, Francis F, Serteyn L. 2021. Distribution of wild bee (Hymenoptera: Anthophila) and hoverfly (Diptera: Syrphidae) communities within farms undergoing ecological transition. Biodivers Data J 9: e60665. DOI: 10.3897/BDJ.9.e60665.

Oksanen J, Blanchet FG, Friendly M. 2017. Package "vegan": Community Ecology Package. R Package version 2.4-4. https: //CRAN.Rproject.org/package1/4vegan.

Piekarska-Boniecka H, Siatkowski M, Trzcinski P, Siatkowski I. 2015. The impact of the vegetation of apple orchard edges on quantity and quality structure of predatory hoverflies (Diptera: Syrphidae) communities. Turk J Entomol 39 (4): 333-343. DOI: 10.16970/ted.92495.

Pimm SL, Jenkins CN, Abell R, Brooks TM, Gittleman JL, Joppa LN, Raven PH, Roberts CM, Sexton JO. 2014. The biodiversity of species and their rates of extinction, distribution, and protection. Science 344: 1246752. DOI: $10.1126 /$ science. 1246752 .

Polatto LP, Chaud-Netto J, Alves-Junior VV. 2014. Influence of abiotic factors and floral resource availability on daily foraging activity of bees. J Insect Behav 27: 593-612. DOI: 10.1007/s10905-014-9452-6.

Popov S, Miličić M, Diti I, Marko O, Sommaggio D, Markov Z, Vujić A. 2017. Phytophagous hoverflies (Diptera: Syrphidae) as indicators of changing landscapes. Comm Ecol 18 (3): 287-294. DOI: 10.1556/168.2017.18.3.7

R Core Team. 2018. R: A Language and Environment for Statistical Computing. R Foundation for Statistical Computing, Vienna, Austria. www.R-project.org/.

Ricarte A, Marcos-García MÁ, Moreno CE. 2011. Assessing the effects of vegetation type on hoverfly (Diptera: Syrphidae) diversity in a Mediterranean landscape: Implications for conservation. J Insect Conserv 15 (6): 865-877. DOI: 10.1007/s10841-011-9384-9.

Ricarte A. 2008. Biodiversidad de sírfdos (Diptera: Syrphidae) y conservación de los hábitats en el Parque Nacional de Cabañeros, España. [Thesis]. Universidad de Alicante, Alicante. [Spain]

Rotheray GE, Gilbert F. 2011. The Natural History of Hoverflies. Forrest Text Publisher, Iver, United Kingdom.

Sajjad A, Saeed S, Ashfaq M. 2010. Seasonal variation in abundance and composition of hoverfly (Diptera: Syrphidae) communities in Multan, Pakistan. Pak J Zool 42 (2): 105-115.

Sanchez-Bayo F, Wyckhuys KG. 2019. Worldwide decline of the entomofauna: A review of its drivers. Biol Conserv 232: 8-27. DOI: 10.1016/j.biocon. 2019.01.020.

Sengupta J, Naskar A, Maity A, Hazra S, Banerjee D. 2016. New distributional records and annotated keys of hoverflies (Insecta: Diptera: Syrphidae) from Himachal Pradesh, India. J Adv Zool 37 (1): 31-54.

Sengupta J, Naskar A, Maity A, Hazra S, Sarkar NK, Banerjee D. 2017. Hover Flies (Diptera: Syrphidae) from Darjeeling Himalaya-A Part of Indo-Burmese Hotspot. Indian J Entomol 79 (3): 336-353. DOI: 10.5958/0974-8172.2017.00065.7

Sengupta J, Naskar A, Maity A, Homechaudhuri S, Banerjee D. 2018. A taxonomic account of Hoverflies (Insecta: Diptera: Syrphidae) with 4 new records from cold dry zones of Himachal Pradesh, India. Intl $\mathbf{J}$ Adv Life Sci Res 1 (4): 13- 30. DOI: 10.31632/ijalsr.2018v01i04.003.

Shebl MA, Kamel SM, Hashesh TAA, Osman MA. 2008. Seasonal abundance of leafcutting bees (Megachile minutissima, Megachilidae, Hymenoptera). World J Agric Sci 4: 280-287. 
Sommaggio D, Burgio G. 2014. The use of Syrphidae as functional bioindicator to compare vineyards with different managements. B Insectol 67: 147-156.

Sommaggio D. 1999. Syrphidae: Can they be used as environmental bioindicators? Agric Ecosyst Environ 74: 343-356. DOI 10.1016/S0167-8809(99)00042-0.

Speight MCD, Sarthou JP. 2017. StN Keys for the Identification of the European Species of Various Genera of Syrphidae 2017. Syrph the Net, the Database of European Syrphidae (Diptera), Syrph the Net publications, Dublin.
Stubbs AE, Falk SJ. 2002. British Hoverflies: An Illustrated Identification Guide. The British Entomology and Natural History Society, United Kingdom.

Talasova A, Straka J, Hadrava J, Benda D, Kocourek F, Kazda J. 2018. High degree of philopatry is required for mobile insects used as local indicators in biodiversity studies. Ecol Indic 94: 99-103. DOI: 10.1016/j.ecolind.2018.06.008.

Thapa VK. 2015. Insect Diversity in Nepal. VK Thapa Publication, Nepal. Thompson F, Rotheray G, Zumbado M. 2010. Syrphidae (flower flies). In: Brown BV (eds). Manual of Central American Diptera, vol. 2. NRC Research Press, Ottawa, Canada. 